\title{
First report of powdery mildew of Polyscias cumingiana caused by Pseudoidium sp. in India
}

\author{
Thite $\mathrm{SV}^{1}$ and Kore BA ${ }^{1}$
}

\author{
${ }^{1}$ Department of Botany, Yashvantrao Chavan Institute of Science, Satara - 415 001, Maharashtra, India \\ Corresponding author E-mail: sachinthiteg4@gmail.com
}

Thite SV, Kore BA 2014 - First report of powdery mildew of Polyscias cumingiana caused by Pseudoidium sp. in India. Plant Pathology \& Quarantine4(2), 108-110, Doi 10.5943/ppq/4/2/5

\begin{abstract}
In January 2014, leaves of Polyscias cumingiana ( $=P$. crispata) with typical symptoms of powdery mildew were collected in the Botanical garden of Yashavantrao Chavan Institute of Science, Satara (MS), India. Based on its morphological characters, the pathogen was identified as Pseudoidium sp. (Erysiphe sp.). This is the first report of powdery mildew on P. cumingiana in India.
\end{abstract}

Key words - Erysiphales - Erysiphe sp. - Araliaceae - Asia.

\section{Introduction}

The Western Ghats, one of the twenty five unique hot spots of biological diversity in the world has a rich and diverse flora and fauna. The western part of Satara (MS, India), falls under Western Ghats and its eastern part exhibits arid conditions. The variations in the altitude, humidity and edaphic factors provide favourable situations for development of all types of ecosystems which inhabit the richest phytodiversity. The natural forest microhabitats and tropical warm humid climatic conditions favour and establish many rare and new fungi.

Well established exotic plants in India are suffering from various new pests and diseases. Polyscias cumingiana (C. Presl) Fern.-Vill. (= P. crispata (Hort. ex W. Bull) M.R. Almeida (Araliaceae) is exotic to India introduced from Brazil for its ornamental value. It is a green, foliar ornamental shrub up to $2 \mathrm{~m}$ tall with triangular leaves, decompound; deeply incised and toothed, oblong to broadly ovate leaflets, alternate with sheathing bases (Fig. 1a). It has three leaflets two larger ones split at the tips and flanking a smaller one. Stems are branched, cylindrical and inflorescence are umbellate. P. cumingiana is mostly a container plant, and has roles in landscape designing and in bonsai.

In January 2014, during routine survey of the Botanical Garden of YCIS, Satara $\left(17^{\circ}\right.$ $42.940^{\prime} \mathrm{N}, 0.73^{\circ} 48.786^{\prime} \mathrm{E}$, Altitude $733 \mathrm{~m}$, Temperature $28^{\circ} \mathrm{C}$, Humidity $57 \%$ ) all plants (28) of $P$. cumingiana were found to be infected with powdery mildew. The plants were fully developed and about one year old. The disease appeared as small irregular, grayish-white powdery spots with very thin effused mycelium on adaxial and abaxial surfaces of leaves (Fig. 1b, c). Infected leaves became at young stage deformed, showing irregular chlorotic patches with curled margin of lamina. Premature leaf fall was also observed. As a result the plants get defoliated and lost their ornamental value. The disease continued up to April 2014 (Temperature $36^{\circ} \mathrm{C}$ and Humidity $36 \%$ ). The disease 
has been collected from many localities in Satara Dist. (MS) and seems to be widespread and common. Based on microscopic examinations, the asexual powdery mildew morph on $P$. cumingiana was easily identifiable as Pseudoidium sp.

\section{Material \& Methods}

Voucher specimen has been deposited in Ajrekar mycological herbarium at Agharkar Research Institute, Pune (MS) India. (Accession No.: AMH - 9643).

\section{Results and Discussion}

Pseudoidium sp. (Erysiphe sp.) on Polyscias cumingiana is morphologically characterized as follows: Mycelium amphigenous, white, thin, forming patches; hyphae hyaline, septate, profusely
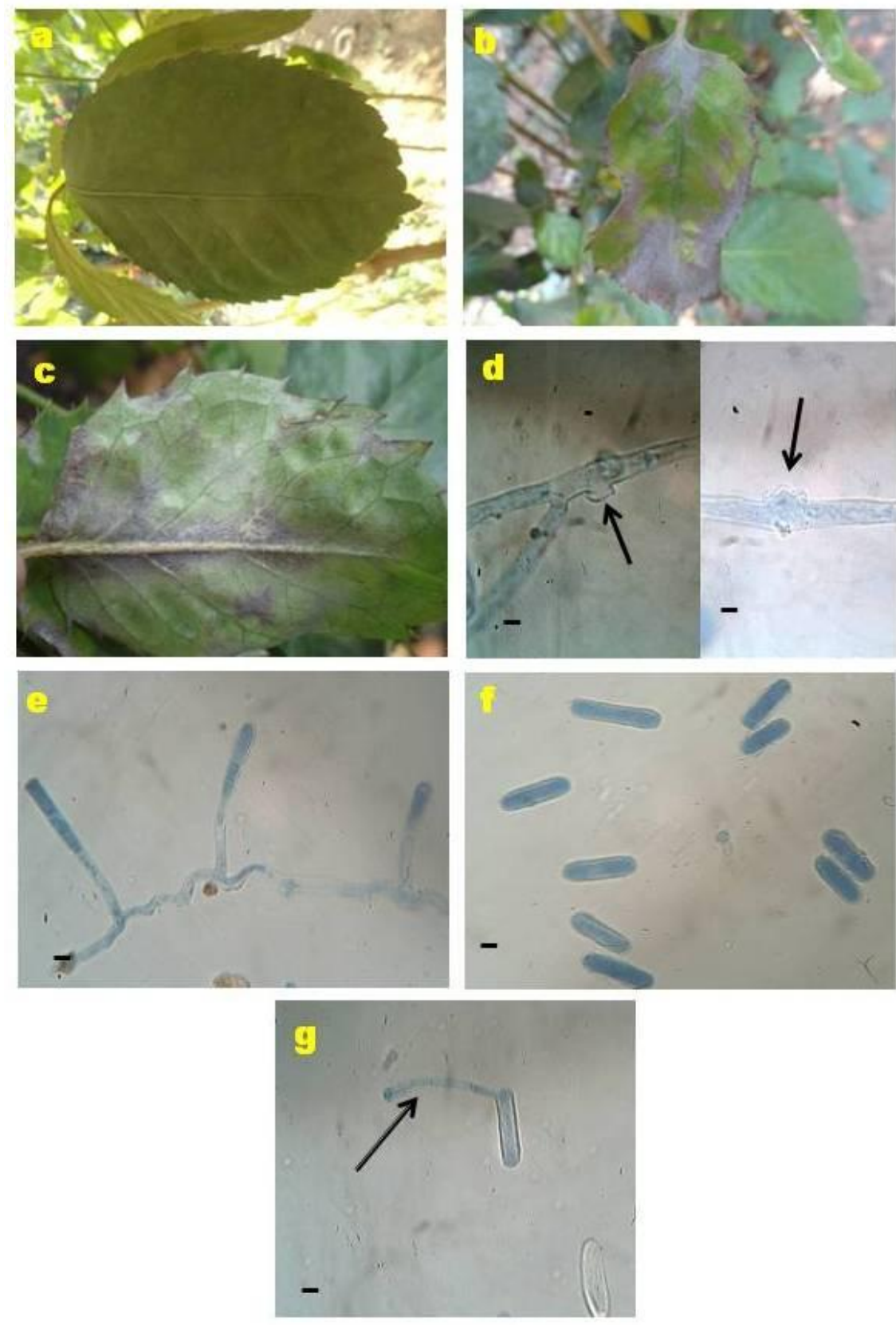

Fig.1 a) Healthy leaflet b) Infected upper surface of leaflet c) Infacted lower surface of leaflet d) Appressoria i- Slightly lobed $($ Bar $=20 \mu \mathrm{m})$,ii- Lobed $($ Bar $=20 \mu \mathrm{m}) \quad$ e) Conidia with conidiophore $(\mathrm{Bar}=20 \mu \mathrm{m}) \mathrm{f})$ Conidia at $45 \mathrm{X}(\mathrm{Bar}=20 \mu \mathrm{m}) \mathrm{g})$ Arrow indicates germinated conidium. 
branched, persistent; hyphal appressoria distinctly or slightly lobed (Fig. 1d). Conidiophores arising from the upper surface of mother cells, erect, foot-cells cylindrical, straight, occasionally somewhat flexuous, $44 \pm 5 \mu \mathrm{m}$, followed by 1-2 shorter cells or sometimes by a cell of about the same length, subsequent cells rarely longer than the foot-cells (Fig. 1e). Conidia formed singly, ovoid, about $39 \pm 4 \times 14 \pm 6 \mu \mathrm{m}$ (Fig. 1f), fibrosin bodies absent, germ tube terminal or subterminal, perihilar, more or less straight, up to $60 \pm 10 \mu \mathrm{m}$, with lobed appressoria at the end (Fig. 1g).

According to the combination of these features, this powdery mildew can be readily identified as species of Pseudoidium Y.S. Paul \& J.N. Kapoor (Braun \& Cook 2012). Based on the new ICN, Pseudoidium is now a heterotypic synonym of Erysiphe DC. The sexual morph (chasmothecia) was not observed.

A literature survey (Bilgrami et al. 1991, Jamaluddin et al. 2004, Paul \& Thakur 2006, Pande 2008, Hosagoudar \& Agarwal 2009, Braun \& Cook 2012, Annonymous 2013) showed that no powdery mildew has been reported on Polyscias spp. in general and on P. cumingiana in India in particular. However, Braun \& Cook (2012) reported Pseudoidium araliacearum (U. Braun \& Oehrens) U. Braun \& R.T.A. Cook on Raukana valdiviensis (Araliaceae) in South America and Erysiphe panacis R.L. Bai \& W.C. Liu (Bai \& Liu 1998) was described from China on Panax (Araliaceae), but the two species are morphologically quite distinct from powdery mildew on Polyscias cumingiana. This is the first report of powdery mildew caused by Pseudoidium sp. (Erysiphe sp.) on Polyscias cumingiana in India and the first record of powdery mildew on Polyscias in general. However, a formal description and naming of this powdery mildew is not justified and not advisable. The sexual morph is unknown. The host plant, which is an exotic ornamental plant in India, is native to SW Pacific Islands, but in its natural areal powdery mildew has never been found. Thus, infections of $P$. cumingiana in India have been possibly caused by native Indian powdery mildews. Such host switches are known. Erysiphe quercicola S. Takam. \& $\mathrm{U}$. Braun is, for instance, known in Asia from a wide range of tree species belonging to unrelated families (Braun \& Cook 2012). Kirschner (2010) demonstrated that Erysiphe magnifica can be transferred from Magnolia to lotus. Results of molecular sequence analyses and corresponding data for comparision are necessary to elucidate the true identity of asexual powdery mildew collections on new hosts.

\section{Acknowledgement}

The authors would like to thank Uwe Braun for confirming the identity of the powdery mildew on P. cumingiana as Pseudoidium sp. and providing the literature. Thanks are also due to Prin. Dr. N.S.Gaikwad and Mr. P. R. Patil, Head, Department of Botany, Y. C. I. S., Satara for providing laboratory facilities.

\section{References}

Annonymous 2013 - Mycobank http://www.mycobank.org/Vizella.

Bai RL, Liu WC. 1998 - A new species of the genus Erysiphe. Mycosystema 17: 119-121.

Bilgrami KS, Jamaluddin MA, Rizwi MA. 1991 - The Fungi of India. Part III (List and References). Today and Tomorrow's Printer and Publishers, New Delhi.

Braun U, Cook RTA. 2012 - Taxonomic manual of the Erysiphales (Powdery Mildews). Fungal Biodiversity Centre (CBS Biodiversity Series No. 11), Utrecht.

Hosagoudar VB, Agarwal DK. 2009 - Powdery mildews of India: Check list. Associated

Publishing Company, New Delhi.

Jamaluddin, Goswami MG, Ojha BM. 2004 - Fungi of India (1989-2001), Scientific Publishers, Jodhapur.

Kirschner R. 2010 - First record of Erysiphe magnifica on lotus, a new host outside the Magnoliales. Mycological Progress 9: 417-424.

Pande A. 2008 - Ascomycetes of Peninsular India. Scientific Publisher, Jodhpur.

Paul YS, Thakur VK. 2006 - Indian Erysiphaceae. Scientific Publishers, Jodhpur. 